\title{
Mast cell chymase affects the proliferation and metastasis of lung carcinoma cells in vitro
}

\author{
YUAN JIANG, YUDAN WU, WILLIAM JAMES HARDIE and XIAOYING ZHOU
}

School of Pharmaceutical Engineering and Life Sciences, Changzhou University, Changzhou, Jiangsu 213164, P.R. China

Received May 17, 2016; Accepted March 14, 2017

DOI: $10.3892 / 01.2017 .6487$

\begin{abstract}
Metastasis of lung carcinoma cells is a major cause of organ failure and mortality of patients with lung cancer. Lung mast cells are a type of immune cell which reside in the respiratory mucosa. High numbers of mast cells are associated with the majority of common types of cancer; however, the effects of mast cells on cancer remain unclear. In the present study, the effects of mast cell chymase (MCC) on the proliferation and adhesion of the lung carcinoma cell lines A549 and $\mathrm{H} 520$ was investigated. After $24 \mathrm{~h}$ of treatment, the highest dose of MCC $(50 \mathrm{mU} / \mathrm{ml})$ decreased the proliferation rate of A549 and $\mathrm{H} 520$ cells, whereas the lowest dose of MCC $(5 \mathrm{mU} / \mathrm{ml})$ resulted in a small increase in the viability. A549 cells treated with MCC lost adhesion ability in a MCC dose-dependent manner; however, these detached cells were able to regrow when transferred to a fresh culture. The protein expression of epithelial (E-) cadherin, p53 and p21 in A549 lung carcinoma cells were detected by western blot analysis. The results of the present study revealed that, following $24 \mathrm{~h}$ of treatment, the expression level of E-cadherin was decreased, the p53 tumor suppressor protein was expressed in limited quantities and the expression of p21 was decreased. Zymography was used to examine the effects of MCC on the expression and activation of matrix metalloproteinase-9 (MMP-9) in A549 and H520 cells. The expression of MMP-9 in the two cell lines was time- and MCC dose-dependent. The results of the present study demonstrated that MCC stimulated lung carcinoma cell proliferation and adhesion, as well as regulated E-cadherin expression and the cell cycle, all of which are associated with cancer metastasis. Therefore, MCC may be a potential candidate for lung carcinoma therapy.
\end{abstract}

Correspondence to: Professor Xiaoying Zhou, School of Pharmaceutical Engineering and Life Sciences, Changzhou University, 1 Gehu Middle Road, Changzhou, Jiangsu 213164, P.R. China

E-mail: xiaoyingzhou@cczu.edu.cn

Key words: mast cell, mast cell chymase (MCC), lung carcinoma, metastasis, proliferation

\section{Introduction}

Morbidity and mortality arising from lung carcinomas account for $17 \%$ of novel cancer cases in humans each year (1), and lung cancer metastasis is the principal reason for organ failure and patient mortality (2). Mast cells are common immune cells that are widely distributed in the respiratory mucosa. Mast cells derive from specific bone marrow cluster of differentiation $34^{+}$precursor cells and migrate to other tissues where the cells mature, depending on the internal environmental conditions (3). Previous studies have revealed that the number of mast cells is increased in various types of cancer, including lung (4), breast (5), prostate (6) and colon (7) cancer. Performing bronchoalveolar lavage on patients with bronchial carcinoma revealed that these patients possess an increased number of mast cells (8-10). In addition, mast cell density has been identified to be associated with cancer progression, angiogenesis and poor prognosis in human adenocarcinomas $(11,12)$.

Mast cell chymase (MCC) (EC 3.4.21.39) is a chymotrypsin-like protease enzyme which is expressed in the secretory granules of mast cells. MCC is able to degrade the extracellular matrix (ECM) of animal tissue (13). ECM turnover involves the alteration of the cellular microenvironment within tissue, and is able to influence carcinoma cell migration, adhesion and relocalization (14). Matrix metalloproteinase-9 (MMP-9) belongs to the class of tissue matrix metalloproteinases which primarily degrade and remodel the ECM (15). MMP-9 has been identified to be an integral part of numerous diseases, including cancer, where modulation of the ECM is a key step (16-18).

Epithelial (E-) cadherin is present in various epithelial cells and tumor cells (19); it is a fundamental component of the adherens junctions (the cytoplasmic connection between neighboring cells) and is known to mediate aggregation-dependent cell survival (20). Loss of E-cadherin gene expression in carcinoma cells may lead to increased cell apoptosis, cell death, cell invasion and metastasis $(21,22)$. The protein p53 is a known carcinoma suppressor which is commonly associated with the pathogenesis of human carcinoma (23). The p53 protein is involved in the response to DNA damage, cell cycle regulation and cell apoptosis (23). This protein also controls cellular progression from $G_{1}$ to $S$ phase in the cell cycle. When cellular DNA is damaged, p53 may initiate the synthesis of $\mathrm{p} 21$, which is a cyclin-dependent kinase (CDK) inhibitor protein. In turn, p21 may combine with cyclin-CDK to form a 
trimer which prevents the damaged cells progressing from $\mathrm{G}_{1}$ to $S$ phase (24).

The aim of the present study was to investigate whether $\mathrm{MCC}$ is involved in carcinoma cytology, the progression to metastasis through degradation of the ECM, cleavage of intercellular connections by proteolysis of E-cadherin and how expression of MMP-9, p53 and p21 proteins were triggered which determine cell apoptosis or cell survival. In the present study, a schematic model of the role of MCC in the fate of lung carcinoma cells was proposed, and it was hypothesized that MCC may affect the biological features of lung cancer cells.

\section{Materials and methods}

Cell lines. A549 human adenocarcinoma alveolar basal epithelial cells and H520 human lung squamous carcinoma cells were purchased from the Cell Bank of the Chinese Academy of Science (Shanghai, China).

Cell viability via the MTT assay. Suspensions of each cell line were conventionally prepared in RPMI-1640 medium (Gibco; Thermo Fisher Scientific, Inc., Waltham, MA, USA) containing 10\% fetal bovine serum (Gibco; Thermo Fisher Scientific, Inc.), and the density was adjusted to $10^{5}$ cells $/ \mathrm{ml}$. Aliquots of $100 \mu \mathrm{l}$ were added to each well of 96-well plates and treated with various concentrations of serum-free human MCC (a gift from Dr A.F. Walls, Southampton University, Southampton, UK) [0(control), $5,25,50$ and $100 \mathrm{mU} / \mathrm{ml}$ or heat-inactivated $\left(65^{\circ} \mathrm{C}\right.$ for $\left.30 \mathrm{~min}\right) \mathrm{MCC}\left(100 \mathrm{mU} / \mathrm{ml}\right.$, incubated at $37^{\circ} \mathrm{C}$ in $5 \% \mathrm{CO}_{2}$ for $6,24,48$ or $72 \mathrm{~h}$ )]. Following incubation for the prescribed time, $10 \mu \mathrm{l}$ MTT (5 mg/ml; Sigma-Aldrich; Merck KGaA, Darmstadt, Germany) was added to each well prior to incubation for another $4 \mathrm{~h}$. In order to solubilize the formazan dye, $150 \mu$ l dimethyl sulfoxide (Sigma-Aldrich; Merck KGaA) was added to each well and the absorbance was determined at $492 \mathrm{~nm}$ using a microplate reader (Thermo Fisher Scientific, Inc.). This protocol was followed three times for each cell line.

Cell adhesion. A suspension of the A549 cell line was adjusted to $10^{6}$ cells $/ \mathrm{ml}$ and co-cultured with MCC $[0,5,25$, 50 and $100 \mathrm{mU} / \mathrm{ml}$ or heat-inactivated MCC $(100 \mathrm{mU} / \mathrm{ml})]$ in centrifuge tubes, with gentle agitation for $30 \mathrm{~min}$ at $50 \mathrm{x} \mathrm{g}$ to avoid cell clumping. Aliquots of $100 \mu$ l each treated cell suspension were transferred to a 96-well plate and incubated for $2 \mathrm{~h}$; this was to allow aggregation of adherent cells, prior to removing the suspension medium, and MTT staining of the unsuspended adherent cells. The MTT assay was performed described as above, the cell adhesion rate (\%) relative to that of the untreated controls was calculated as follows: [Optical density (OD) value of the experimental group/OD value of the control group]x $100 \%$.

Cell re-adhesion and survival. Following MCC treatment as aforementioned, a number of cells detached from adherent clusters and remained suspended in the culture medium, and were therefore not included in the MTT analysis. To investigate whether those suspended cells had undergone apoptosis, or whether the cells may become re-adherent under altered conditions, fresh cell suspensions $\left(1 \times 10^{5} \mathrm{cells} / \mathrm{ml}\right)$ were prepared as aforementioned and co-cultured with MCC $[(0,25$ and $100 \mathrm{mU} / \mathrm{ml}$ or heat-inactivated MCC $(100 \mathrm{mU} / \mathrm{ml})$ for 6 , 24,48 or $72 \mathrm{~h}$ ]. Following stimulation with MCC, the medium containing the detached cells was carefully transferred from each of the treated new wells, using separate sterile pipettes, into separate wells containing fresh MCC-free RPMI-1640 medium. The plate was incubated at $37^{\circ} \mathrm{C}$ for $2 \mathrm{~h}$ to allow the cells to aggregate at the bottom of the wells. The MTT method as described above was used to determine the re-adhesion rate of the cells.

Western blot analysis. Following treatment with $\operatorname{MCC}(0,25$ or $50 \mathrm{mU} / \mathrm{ml})$ or heat-inactivated MCC $(100 \mathrm{mU} / \mathrm{ml})$ for $24 \mathrm{~h}$, the cells were lysed using radioimmunoprecipitation assay buffer, and protein was quantified using the bicinchoninic acid protein assay (Sigma-Aldrich; Merck KGaA). A total of $20 \mu \mathrm{g}$ extracted protein/lane was treated with sample buffer containing $5 \mathrm{mM}$ dithiothreitol at $95^{\circ} \mathrm{C}$ for $10 \mathrm{~min}$. The samples were then separated by SDS-PAGE (10\% gel) and transferred onto a polyvinylidene fluoride membrane (EMD Millipore, Billerica, MA, USA). The non-specific binding sites were blocked with a solution of 5\% skimmed milk in PBS containing $0.1 \%$ Tween-20 (Sigma-Aldrich; Merck KGaA). The primary antibodies against p53 (cat. no. sc-099; Santa Cruz Biotechnology, Inc., Dallas, TX, USA), p21 (cat. no. sc-817; Santa Cruz Biotechnology, Inc.) and E-cadherin (cat. no. sc-1500; Invitrogen; Thermo Fisher Scientific, Inc.) were diluted 1:500. The membrane was incubated overnight at $4^{\circ} \mathrm{C}$. The corresponding horseradish peroxidase-conjugated anti-mouse secondary antibody was diluted 1:500 and added to the membrane for $1 \mathrm{~h}$ at room temperature. Enhanced chemiluminescence (PerkinElmer, Inc., Waltham, MA, USA) was used to develop the blot and the images were captured using a ChemiDoc ${ }^{\mathrm{TM}} \mathrm{CRS}^{+}$Molecular Imager (Bio-Rad Laboratories, Inc., Hercules, CA, USA).

Zymography. Aliquots of $20 \mu \mathrm{l}$ serum-free cell culture medium containing MCC-treated $(0,5,25$ or $50 \mathrm{mU} / \mathrm{ml})$ cells were taken from the incubated plate wells, mixed with $10 \mu \mathrm{l}$ sample buffer solution ( $0.5 \mathrm{M}$ Tris-HCl, 50\% glycerol, $10 \%$ SDS and $0.1 \%$ bromophenol blue), loaded onto $8 \%$ polyacrylamide gels containing $1 \mathrm{mg} / \mathrm{ml}$ gelatin (Sigma-Aldrich; Merck KGaA) and run at $100 \mathrm{~V}$ until the blue dye had reached the bottom of the gel. Following electrophoresis, SDS was removed from the gel using 2.5\% Triton X-100 (Sigma-Aldrich; Merck KGaA) for $1 \mathrm{~h}$ at room temperature. The gels were subsequently incubated overnight in an MMP developing buffer (50 mM Tris- $\mathrm{HCl}, 25 \mathrm{mM}$ $\mathrm{NaCl}$ and $7 \mathrm{mM} \mathrm{CaCl}_{2}$ ) at $37^{\circ} \mathrm{C}$ with agitation. Subsequently, the gels were stained with $0.2 \%$ Coomassie brilliant blue for 30 min and counterstained using a mixture of $10 \%$ acetic acid, $50 \%$ methanol and $40 \%$ distilled water. Semi-quantification was carried out using Image Lab software (version 7.0; Bio-Rad Laboratories, Inc.), and alterations in the density of the bands were calculated as percentages relative to untreated controls.

Statistical analysis. Statistical analysis was performed using GraphPad Prism software (version 5.0; GraphPad Software, Inc., La Jolla, CA, USA). Student's t-test was carried out, and the data were presented as the mean \pm standard deviation $(n=3-6) . P<0.05$ was considered to indicate a statistically significant difference, and $\mathrm{P}<0.01$ was considered to indicate a highly statistically significant difference. 
A

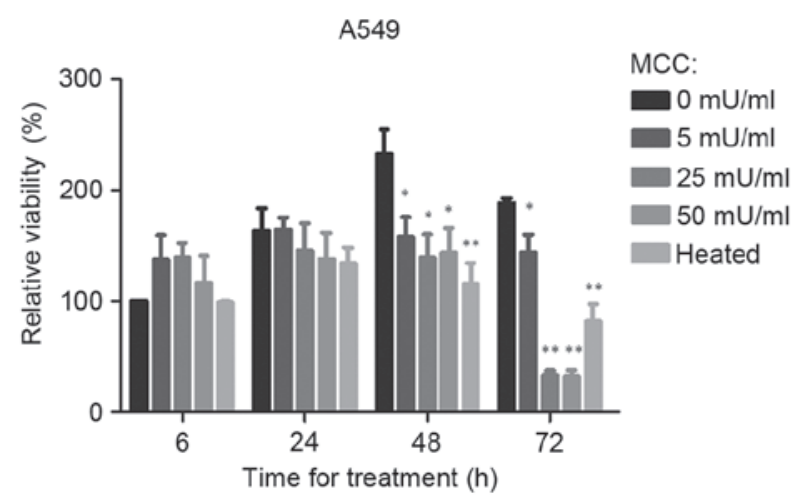

B

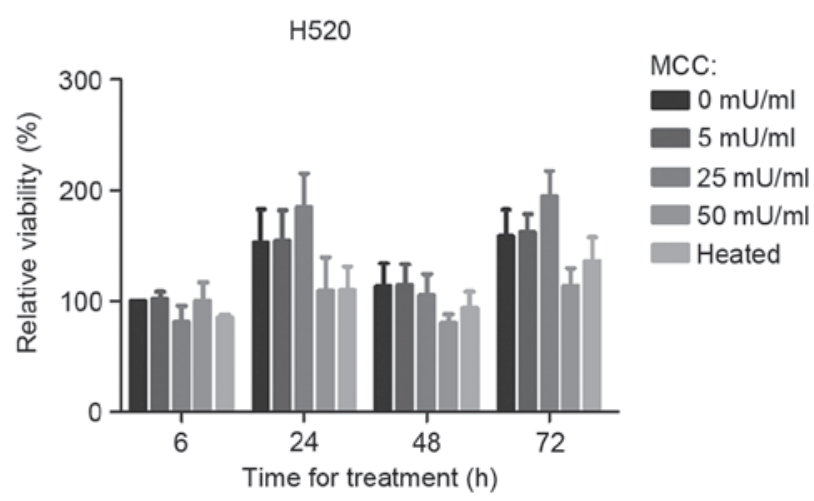

Figure 1. Effects of various concentrations of MCC on (A) A549 and (B) H520 cell viability relative to untreated cells, determined using an MTT assay. Results are the mean \pm standard deviation of three experiments. ${ }^{*} \mathrm{P}<0.05 ;{ }^{* *} \mathrm{P}<0.01$ vs. untreated control using Student's t-test. MCC, mast cell chymase.

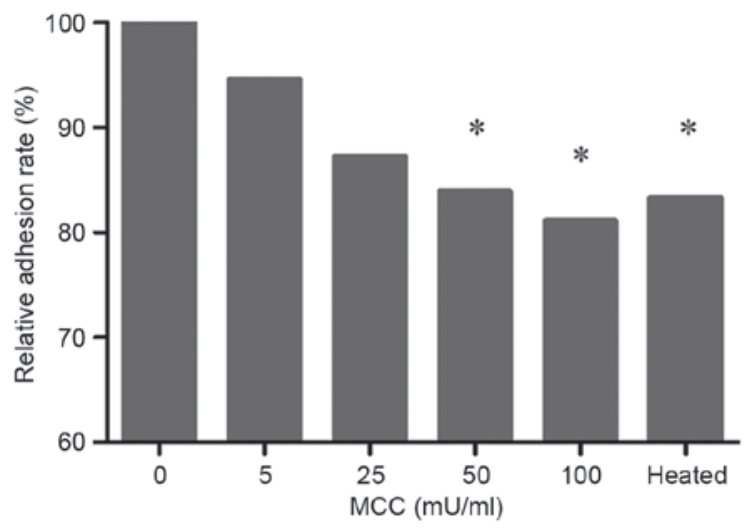

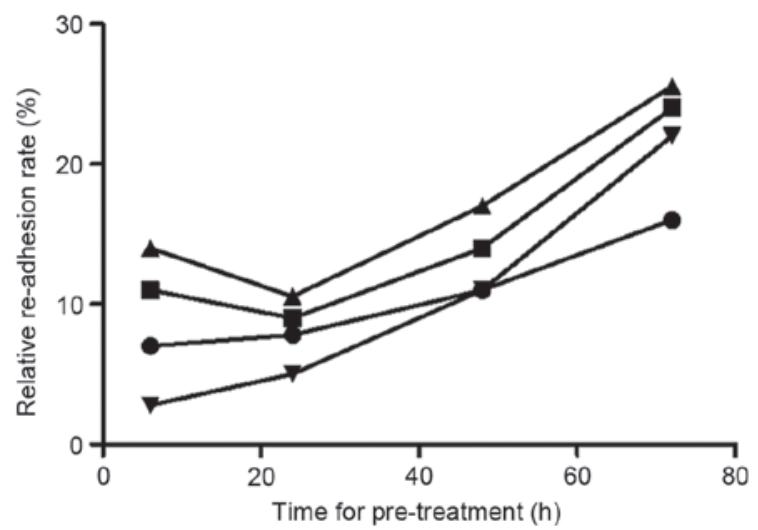

Figure 2. Effects of MCC on lung carcinoma cell adhesion. (A) A549 cells were mixed with various concentrations of MCC. Results are the mean \pm standard deviation of three experiments. (B) Re-adhesion rates of suspended A549 cells induced by $\mathrm{MCC}$ treatment ( $0 \mathrm{mU} / \mathrm{ml} ; \bullet 25 \mathrm{mU} / \mathrm{ml}$; $\boldsymbol{\Delta} 100 \mathrm{mU} / \mathrm{ml}$; $\boldsymbol{\nabla}$ heat-inactivated MCC $100 \mathrm{mU} / \mathrm{ml})$. ${ }^{*} \mathrm{P}<0.05$ vs. untreated control using Student's t-test. MCC, mast cell chymase.

\section{Results}

Effects of MCC on lung cancer cell viability. When A549 cells were treated with MCC for $6 \mathrm{~h}$, their relative viability was slightly increased. Compared with the untreated control, treatment of A549 cells for $48 \mathrm{~h}$ with 5,25 and $50 \mathrm{mU} / \mathrm{ml} \mathrm{MCC}$ significantly decreased the relative viability $(\mathrm{P}<0.05$; Fig. $1 \mathrm{~A})$ as did heat-inactivated MCC ( $\mathrm{P}<0.01$; Fig. 1A). In H520 cells, a small inhibitory effect from $50 \mathrm{mU} / \mathrm{ml} \mathrm{MCC}$ on cell viability was observed, although no significant difference between cells treated with MCC and the untreated control group were identified (Fig. 1B).

Effects of MCC on A549 cell adhesion. The MTT assay, carried out on suspended cells mixed with various concentrations of MCC, revealed that, with increasing MCC concentration, the relative adhesion rate of lung cancer cell decreased (50 and $100 \mathrm{mU} / \mathrm{ml} ; \mathrm{P}<0.05$; Fig. 2A).

A549 cell re-adhesion and survival. The detached cells induced by MCC were washed and relocated to new wells without MCC in order to promote re-adhesion of these cells (Fig. 2B). The re-adhesion rate was time- and dose-dependent.

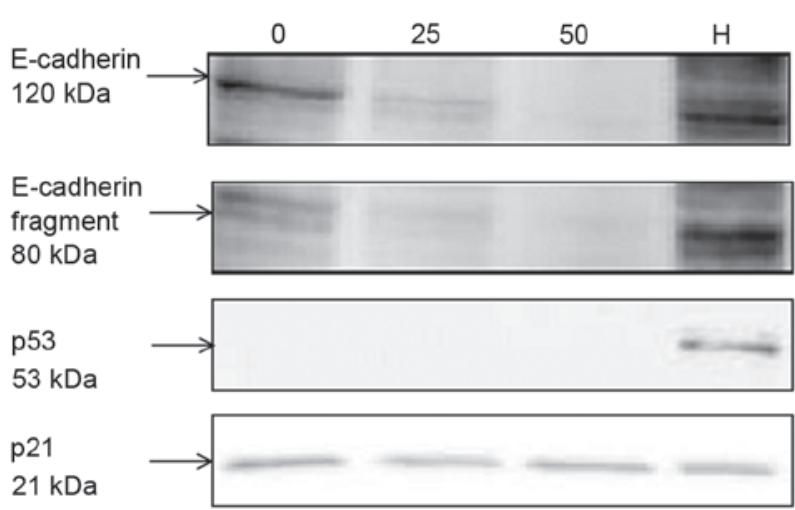

Figure 3. Expression levels of E-cadherin, p53 and p21 in A549 cells following MCC treatment for $24 \mathrm{~h}$. The cells were treated with various concentrations of $\operatorname{MCC}(0,25$ and $50 \mathrm{mU} / \mathrm{ml})$ and heat-inactivated MCC. E-cadherin, epithelial cadherin; MCC, mast cell chymase; $\mathrm{H}$, heat-inactivated MCC.

Effects of MCC on E-cadherin expression and regulation of p53 and p 21 levels in A549 cells. As presented in Fig. 3, following $24 \mathrm{~h}$ of treatment with 25 and $50 \mathrm{mU} / \mathrm{ml} \mathrm{MCC}$, the expression level of E-cadherin was decreased and E-cadherin 

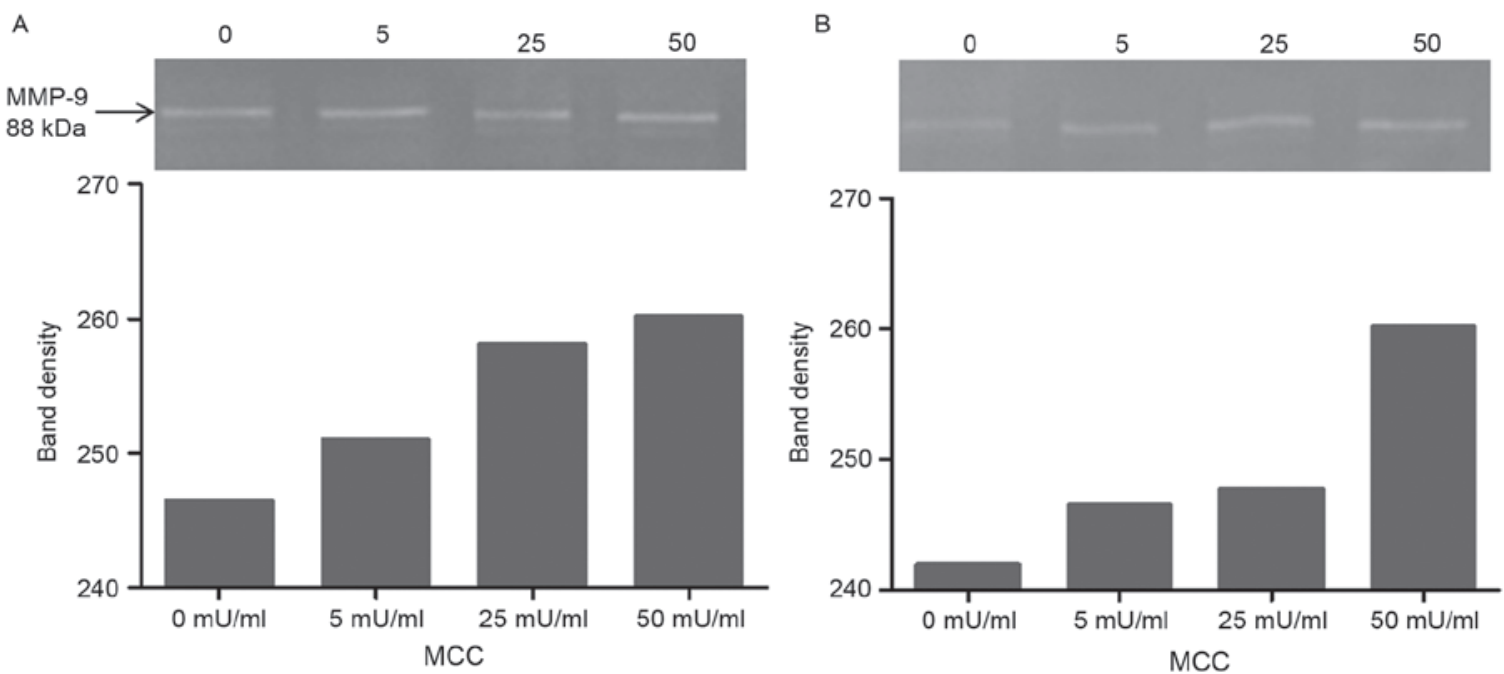

Figure 4. Effect of MCC activity on MMP-9 expression and activation of lung carcinoma cells using gelatin zymography analysis. The supernatant of (A) A549 and (B) H520 cells after $24 \mathrm{~h}$ of treatment with MCC (0, 5, 25 and $50 \mathrm{mU} / \mathrm{ml})$. The bands indicate the areas of MMP-9 proteolysis. MMP-9, matrix metalloproteinase 9; MCC, mast cell chymase.

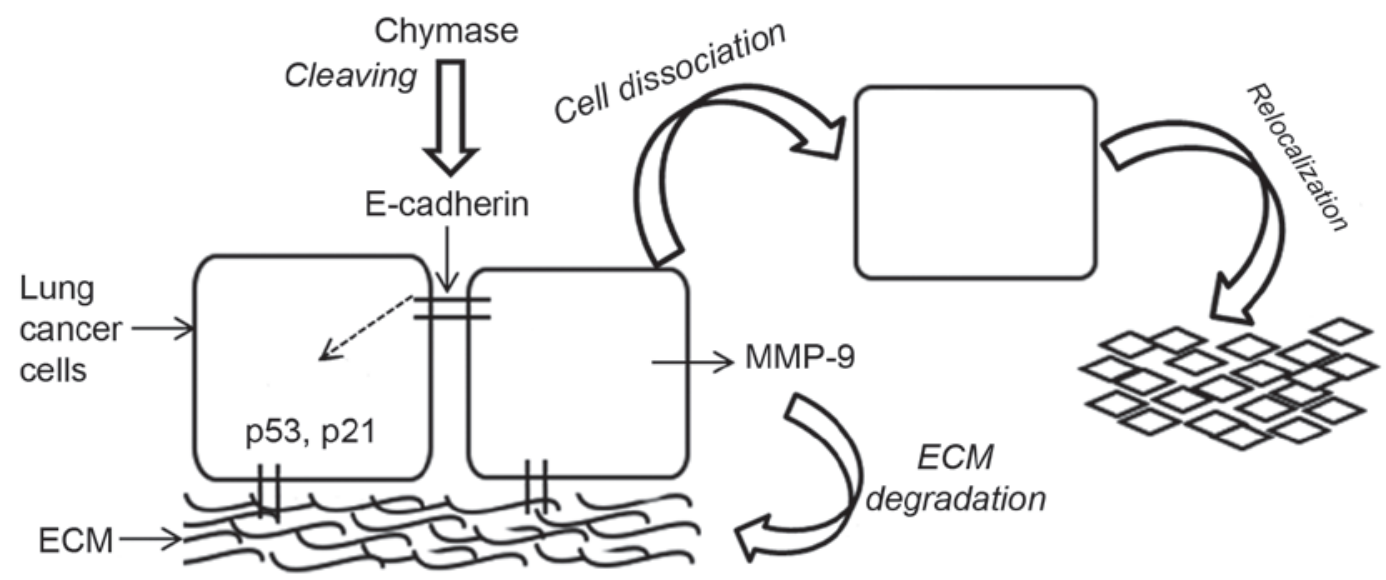

Figure 5. Schematic diagram of the role of mast cell chymase in lung carcinoma ECM degradation, cell dissociation and relocalization which leads to metastasis. ECM, extracellular matrix; MMP-9, matrix metalloproteinase 9; E-cadherin, epithelial cadherin.

fragment expression was identified using normal medium and heat-inactivated MCC. The p53 tumor suppressor protein was expressed in limited quantities in the A549 cells; conversely, decreased expression was exhibited by A549 cells treated with 25 and $50 \mathrm{mU} / \mathrm{ml}$ MCC, compared with untreated cells.

Effects of MCC on MMP-9 expression in A549 and H52O carcinoma cells. The results of the zymography assay demonstrated that increased concentrations of MCC treatment resulted in increased MMP-9 expression levels in A549 (Fig. 4A) and H520 (Fig. 4B) cell lines.

\section{Discussion}

Previous studies have demonstrated that the accumulation of bone marrow-derived cells, including mast cells, serves an important role in cancer tumor growth and angiogenesis $(8,12)$. Despite this, and the historic speculation surrounding this topic, a limited number of studies have addressed the interactions between mast cells and cancer cells $(9,25)$. Furthermore, although MCC is well-characterized and its proteolytic effect on the extracellular matrix is well known, a broader role for this enzyme in carcinoma cytology and metastasis has, to the best of our knowledge, not been investigated previously. Accordingly, the effect of MCC on the proliferation and adhesion of lung cancer cells, as well as cell growth-associated factors p53 and p21 were investigated in the present study. Fig. 5 presents a schematic diagram of the events triggered by MCC.

The results of the present study indicated that MCC exerts various effects on lung cancer cells, depending on its activity and exposure time. Compared with the untreated control, MCC treatment for $6 \mathrm{~h}$ resulted in a slight increase in A549 cell numbers; however, MCC treatment for $24 \mathrm{~h}$ caused the numbers of A549 and H520 cells to decrease. Notably, the inhibitory effect of MCC on cell proliferation was time-dependent, as observed in the cells following $24 \mathrm{~h}$ of treatment. Treating cells with the lowest concentration of MCC $(5 \mathrm{mU} / \mathrm{ml})$ resulted in increased cell viability, whereas the higher doses of MCC ( 25 and $50 \mathrm{mU} / \mathrm{ml}$ ) caused decreased 
viability of A549 and H520 cell lines. Similar results were observed with MCC treated human epithelial cells (26). The duration and the activity of MCC also influenced the cell cycle where p53 and p21 are involved.

The weakening of cell-cell adhesion is particularly important for the metastasis of cancer cells (27). Cadherins are considered to be the most important group of molecules involved in cell-cell and cell-matrix adhesion (28). Decreased expression of E-cadherin has been associated with more advanced tumor stages and grades for lung (29), gastric tract (30), breast (31), bladder (32), colorectal (33) and prostate (34) cancer. Lower expression of E-cadherin in cancer cells rendered them prone to invasion and promoted metastasis $(21,35)$. Following $24 \mathrm{~h}$ of treatment with MCC (25 and $50 \mathrm{mU} / \mathrm{ml}$ ), the expression of E-cadherin was decreased; a result that was consistent with cell adhesion data for A549. The loss of E-cadherin expression may induce cell dissociation and trigger a downstream intracellular signaling pathway, resulting in deregulation of the cell cycle. However, as the results of the present study demonstrated, cell dissociation may eventually result in apoptosis, metastasis and re-adherence, under altered conditions.

The p53 tumor suppressor protein is a key regulator of programmed cell death (apoptosis) including anoikis (36), a form of apoptosis induced by the detachment of cells from the ECM or cell clusters. Cell cycle deregulation is common in human cancer. Alterations of the tumor-suppressor protein p53 and its downstream effector, $\mathrm{p} 21$, have been indicated in the development of a number of human malignancies (24). The protein p21 is a regulator of cell cycle progression at $\mathrm{G}_{1}$ and $\mathrm{S}$ phase, and, additionally, mediates cellular senescence (37). The expression of p53 was down-regulated in the A549 cells treated with MCC (25 and $50 \mathrm{mU} / \mathrm{ml})$, compared with untreated cells. Notably, the A549 cells treated with heat-inactivated MCC $(50 \mathrm{mU} / \mathrm{ml})$ expressed increased levels of p53 protein, indicating that the effects of MCC on lung cancer cells are associated with the activity of the enzyme.

The process of metastasis involves cell-cell and cell-ECM interactions by the actions of proteolytic enzymes which facilitate breakdown and invasion of the basement membrane (38). Conversely, the loss of cell attachment to ECM or cells may induce cell apoptosis (anoikis). Therefore, cell adhesion, for survival, and cell disassociation, for migration and re-establishment (metastasis), are key aspects of the present study. MCC-dissociated cells formed clusters at the bottom of the culture wells. At the highest MCC concentration $(100 \mathrm{mU} / \mathrm{ml}), 20 \%$ of the cells lost attachment and migrated into the cell culture medium; however, when transferred to a novel culture environment, only $50 \%$ of those suspended cells proliferated and became re-adherent. Additionally, subsequent co-culture of the cell suspension with various concentrations of MCC led to a dose-dependent effect on the cell adhesion rate.

Degradation of the ECM is the primary function of matrix metalloproteinase, which allows cell clusters to be separated. Previous studies have demonstrated that MMP-2 and MMP-9 are involved in tumor invasion and metastasis of gastric system (17), colon (16), breast (39), head and neck (18) and lung (40) cancers. In the present study, MMP-9 expression levels in lung cancer cells was associated with the activity of
MCC. With the increase in concentration of MCC, MMP-9 expression in A549 and H520 cells were increased. In addition, MCC-induced expression of MMP-9 was time-dependent and the present study provides the first indication, to the best of our knowledge, that MCC affects the expression of MMP-9 in lung cancer cells and the activation of cancer cells themselves. The present study additionally revealed that MCC is involved in ECM turnover and is associated with lung cancer cell migration and metastasis.

The adhesion and relocalization of lung cancer cells was affected by MCC-associated cell E-cadherin expression and the expression of the cell cycle regulators p21 and p53. MCC was revealed to influence MMP-9 expression and activation of lung cancer cells, and serves a role in ECM degradation enabling the cell clusters to separate, proliferate and relocate.

The results of the present study identified that MCC triggers a cascade of responses associated with the proliferation, adhesion and migration of lung cancer cells. Low doses were able to induce proliferation and high doses of MCC inhibited the proliferation of lung cancer cells. In addition, MCC may affect adhesion molecules, resulting in tumor cell detachment and in cell migration or apoptosis. The results of the present study indicate that $\mathrm{MCC}$ is a promising candidate for lung cancer therapy.

\section{Acknowledgements}

The present study was supported by Changzou University (grant no. ZMF14020066) and Changzhou Science and Technology Bureau (grant no. KYJ1520305) to X.Z.

\section{References}

1. Jemal A, Bray F, Center MM, Ferlay J, Ward E and Forman D: Global cancer statistics. CA Cancer J Clin 61: 69-90, 2011.

2. Siegel R, Naishadham D and Jemal A: Cancer statistics, 2012. CA Cancer J Clin 62: 10-29, 2012.

3. Krishnaswamy G, Ajitawi O and Chi DS: The human mast cell: An overview. Methods Mol Biol 315: 13-34, 2005.

4. Takanami I, Takeuchi K and Naruke M: Mast cell density is associated with angiogenesis and poor prognosis in pulmonary adenocarcinoma. Cancer 88: 2686-2692, 2000.

5. Rajput AB, Turbin DA, Cheang MC, Voduc DK, Leung S, Gelmon KA, Gilks CB and Huntsman DG: Stromal mast cells in invasive breast cancer are a marker of favorable prognosis: A study of 4,444 cases. Breast Cancer Res Treat 107: 249-257, 2008.

6. Johansson A, Rudolfsson S, Hammarsten P, Halin S, Pietras K, Jones J, Stattin P, Egevad L, Granfors T, Wikström P and Bergh A: Mast cells are novel independent prognostic markers in prostate cancer and represent a target for therapy. Am J Pathol 177: 1031-1041, 2010.

7. Blatner NR, Bonertz A, Beckhove P, Cheon EC, Krantz SB, Strouch M, Weitz J, Koch M, Halverson AL, Bentrem DJ and Khazaie K: In colorectal cancer mast cells contribute to systemic regulatory T-cell dysfunction. Proc Natl Acad Sci USA 107: 6430-6435, 2010.

8. Ozdemir O: The role of mast cell density in tumor-associated angiogenesis and survival of squamous cell carcinoma of the lung. J Cancer Res Ther 11: 1041, 2015.

9. Khazaie K, Blatner NR, Khan MW, Gounari F, Gounaris E, Dennis K, Bonertz A, Tsai FN, Strouch MJ, Cheon E, et al: The significant role of mast cells in cancer. Cancer Metastasis Rev 30: 45-60, 2011.

10. Nagata M, Shijubo N, Walls AF, Ichimiya S, Abe S and Sato N: Chymase-positive mast cells in small sized adenocarcinoma of the lung. Archiv Für Pathologische Anatomie Und Physiologie Und Für Klinische Medicin 443: 565-573, 2003. 
11. Maltby S, Khazaie K and McNagny KM: Mast cells in tumor growth: Angiogenesis, tissue remodelling and immune-modulation. Biochim Biophys Acta 1796: 19-26, 2009.

12. Theoharides TC, Angelidou A and Zhang B: Mast cells and tumor microenvironment. Cancer Drug Discovery Development: 353-370, 2010.

13. Stewart JA Jr, Wei CC, Brower GL, Rynders PE, Hankes GH, Dillon AR, Lucchesi PA, Janicki JS and Dell'Italia LJ: Cardiac mast cell- and chymase-mediated matrix metalloproteinase activity and left ventricular remodeling in mitral regurgitation in the dog. J Mol Cell Cardiol 35: 311-319, 2003.

14. Seth D, D'Souza El-Guindy NB, Apte M, Mari M, Dooley S, Neuman M, Haber PS, Kundu GC, Darwanto A, de Villiers WJ, et al: Alcohol, signaling, and ECM turnover. Alcohol Clin Exp Res 34: 4-18, 2010.

15. Christensen J and Shastri VP: Matrix-metalloproteinase-9 is cleaved and activated by Cathepsin K. Bmc Res Notes 8: 322 , 2015.

16. Murnane MJ, Cai J, Shuja S, McAneny D, Klepeis V and Willett JB: Active MMP-2 effectively identifies the presence of colorectal cancer. Int J Cancer 125: 2893-2902, 2009.

17. Cupić DF, Tesar EC, Ilijas KM, Nemrava J and Kovacević M: Expression of matrix metalloproteinase 9 in primary and recurrent breast carcinomas. Coll Antropol 35 (Suppl 2): S7-S10, 2011

18. Werner G, Daniele M, Gabriella N, Lorenzo M, Giovanni T and Renato G: Association between metalloproteinases 2 and 9 activity and ERK1/2 phosphorylation status in head and neck cancers: An ex vivo study. Oncol Rep 24: 1073-1078, 2010.

19. Lecuit T and Yap AS: E-cadherin junctions as active mechanical integrators in tissue dynamics. Nat Cell Biol 17: 533-539, 2015

20. Zhao P, Guo S, Tu Z, Di L, Zha X, Zhou H and Zhang X: Grhl3 induces human epithelial tumor cell migration and invasion via downregulation of E-cadherin. Acta Biochim Biophys Sin (Shanghai) 48: 266-274, 2016.

21. Techasen A, Loilome W, Namwat N, Khuntikeo N, Puapairoj A, Jearanaikoon P, Saya $\mathrm{H}$ and Yongvanit P: Loss of E-cadherin promotes migration and invasion of cholangiocarcinoma cells and serves as a potential marker of metastasis. Tumour Biol 35 8645-8652, 2014.

22. Chen A, Beetham H, Black MA, Priya R, Telford BJ Guest J, Wiggins GA, Godwin TD, Yap AS and Guilford PJ: E-cadherin loss alters cytoskeletal organization and adhesion in non-malignant breast cells but is insufficient to induce an epithelial-mesenchymal transition. Bmc Cancer 14: 552, 2014.

23. Muller PA and Vousden KH: Mutant p53 in cancer: New functions and therapeutic opportunities. Cancer Cell 25: 304-317, 2014.

24. Sivoňová MK, Vilčková M, Kliment J, Mahmood S, Jurečeková J, Dušenková S, Waczulíková I, Slezák P and Dobrota D: Association of $\mathrm{p} 53$ and $\mathrm{p} 21$ polymorphisms with prostate cancer. Biomed Rep 3: 707-714, 2015.

25. Ribatti D and Crivellato E: Mast cells, angiogenesis, and tumour growth. Biochim Biophys Acta 1822: 2-8, 2012.

26. Zhou X, Cox C, Rajenthirar S, Mahrous AA, Masters B, Roche WR and Walls AF: Mast cell Chymase Can Disrupt the human bronchial epithelium and stimulate the loss of adhesion molecules. J Allergy Clinical Immunol 121: S110, 2008.
27. Lee HS and Daar IO: EphrinB reverse signaling in cell-cell adhesion: Is it just par for the course? Cell Adh Migr 3: 250-255, 2008

28. Segal L, Katz LS, Shapira H, Sandbank J, Geras-Raaka E, Gershengorn MC and Oron Y: PAR-3 knockdown enhances adhesion rate of PANC-1 cells via increased expression of integrinov and E-cadherin. PLoS One 9: e93879, 2014.

29. Cui T, Srivastava AK, Han C, Yang L, Zhao R, Zou N, Qu M, Duan W, Zhang X and Wang QE: XPC inhibits NSCLC cell proliferation and migration by enhancing E-Cadherin expression. Oncotarget 6: 10060-10072, 2015.

30. Waldum HL, Ringnes E, Nordb $\varnothing \mathrm{H}$, Sørdal $\varnothing$, Nordrum IS and Hauso Ø: The normal neuroendocrine cells of the upper gastrointestinal tract lack E-cadherin. Scand J Gastroentero 49: 974-978, 2014.

31. Yamashita N, Tokunaga E, Inoue Y, Tanaka K, Ueo H, Saeki H, Oki K and Maehara Y: Abstract P2-05-12: Epithelial paradox; clinical significance of co-expression of E-cadherin and vimentin in invasive breast cancer. Cancer Res 76: 2016

32. Wu CL, Ho JY, Chou SC and Yu DS: MiR-429 reverses epithelial-mesenchymal transition by restoring E-cadherin expression in bladder cancer. Oncotarget 7: 26593-26603, 2016.

33. Dass SD, Cheah PL, Ong DB, Teoh KH and Looi LM: E-cadherin downregulation at the infiltrating tumour front is associated with histological grade and stage in colorectal carcinoma of Malaysians. Malays J Pathol 37: 19-24, 2015.

34. Nam RK, Benatar T, Wallis CJ, Amemiya Y, Yang W, Garbens A, Naeim M, Sherman C, Sugar L and Seth A: MiR-301a regulates E-cadherin expression and is predictive of prostate cancer recurrence. Prostate 76: 869-884, 2016.

35. Ma B, Zhang HY, Bai X, Wang F, Ren XH, Zhang L and Zhang MZ: ADAM10 mediates the cell invasion and metastasis of human esophageal squamous cell carcinoma via regulation of E-cadherin activity. Oncol Rep 35: 2785-2794, 2016.

36. Wang X, Simpson ER and Brown KA: p53: Protection against tumor growth beyond effects on cell cycle and apoptosis. Cancer Res 75: 5001-5007, 2015.

37. McNaughton M, Pitman M, Pitson SM, Pyne NJ and Pyne S: Proteasomal degradation of sphingosine kinase 1 and inhibition of dihydroceramidedesaturase by the sphingosine kinase inhibitors, SKi or ABC294640, induces growth arrest in androgen-independent LNCaP-AI prostate cancer cells. Oncotarget 7: 16663-16673, 2016.

38. Liu Z, Liu Z, Zhang X, Xue P and Zhang H: RY10-4 suppressed metastasis of MDA-MB-231 by stabilizing ECM and E-cadherin. Biomed Pharmacother 68: 439-445, 2014.

39. Sullu Y, Demirag GG, Yildirim A, Karagoz F and Kandemir B: Matrix metalloproteinase-2 (MMP-2) and MMP-9 expression in invasive ductal carcinoma of the breast. Pathol Res Pract 207: 747-753, 2011.

40. Peng WJ, Zhang JQ, Wang BX, Pan HF, Lu MM and Wang J: Prognostic value of matrix metalloproteinase 9 expression in patients with non-small cell lung cancer. Clinica Chim Acta 413: 1121-1126, 2012 